\title{
Differences between Members and Shareholders of a Friendly Society and the Payment of Dividends: A South African-Australian Perspective
}

\section{P.E.R}

Pioneer in peer-reviewed, open access online law publications

Author

Neels Kilian

Affiliation

North-West University

South Africa

Email

\section{corneliuskilian@hotmail.com}

Date Submission

28 October 2020

Date Revised

2 June 2021

Date Accepted

2 June 2021

Date published

18 June 2021

Editor Dr TV Warikandwa

How to cite this article

Kilian N "Differences between Members and Shareholders of a Friendly Society and the Payment of Dividends: A South AfricanAustralian Perspective" PER / PELJ 2021(24) - DOI http://dx.doi.org/10.17159/17273781/2021/v24i0a10733

\section{Copyright}

DOI

http://dx.doi.org/10.17159/17273781/2021/v24i0a10733

\begin{abstract}
This article focusses on a very specific problem statement, namely how shareholder society relationships are viewed in Australia and South Africa. Friendly societies are special "legal creatures" enjoying legal personality from the date and time of their registration (not as companies). In South Africa friendly societies have been in existence for more than 160 years, with the latest legislation being promulgated in 1956. As an unregistered company, the friendly society forms part of the South African business enterprise landscape and has both members and shareholders. The legal relationships between members and shareholders and the payment of a dividend are unclear in the Friendly Society Act, 1956, and are generally regulated by the constitution or memorandum of incorporation of the friendly society. In Australia friendly societies developed approximately 200 years ago. In 1999 friendly society legislation was repealed by the Financial Sector Reform Act, 1999, in terms of which friendly societies had to convert to companies either as companies limited by guarantee or public companies as regulated by the Corporations Act, 2001. Prior to 1999, friendly societies were largely regulated by the Queensland Friendly Society Act, 1997 as unregistered companies. The Code regulated the relationships between members and shareholders and the payment of dividends. In this article we also focus on Australian friendly societies after 1999 and how they compare with South African friendly societies with regard to the member/shareholder relationships and the payment of dividends.
\end{abstract}

\section{Keywords}

Shareholder; friendly society; friendly society benefits; friendly society loss ratio; member; committee of officers; shares; cumulative shares; dividends. 


\section{Introduction}

In order to understand a friendly society as an enterprise, the following brief historical overview is important. The legislative history of South African friendly societies consists of various pieces of legislation. For example, the oldest piece of legislation commenced in Natal in $1862 .{ }^{1} \mathrm{~A}$ friendly society is a special "legal creature". It differs from a company although it has some features similar to those of a company. For example, a committee of officers is similar to a board of directors. ${ }^{2}$ In brief, prior to 1899 South African friendly societies existed predominantly as separate "legal creatures" in the Cape Colony, Natal (colonies of the United Kingdom), and the South African Republic (hereafter ZAR). ${ }^{3}$ The Orange Free State and the ZAR, each with its own appointed government, promulgated their own legislation. ${ }^{4}$ After the Anglo-Boer War and in 1910 during the phase of amalgamating Natal, the Cape Colony, the Orange Free State and the Transvaal or ZAR into one State - the Union of South Africa - each "colony" continued to exist as an individual province of the Union. It seems that each province could adopt its own legislation or continue with existing legislation promulgated prior the Anglo Boer War or even before 1910. A practical example is the Transvaal Companies Act 31 of 1909, which regulated companies in the Transvaal only. ${ }^{5}$ Transvaal friendly societies are mentioned in section 202 of this Act,

Neels Kilian. MA (Regensburg) LLM (UP) LLD (UFS). Faculty of Law, North-West University, South Africa. E-mail: corneliuskilian@hotmail.com. ORCiD: https://orcid.org/0000-0002-2890-9350. The opinions and/or views in this article are those of the researcher and do not reflect the views and or opinions of the NorthWest University. I accept full responsibility for any inaccuracies.

$1 \quad$ See in general Wettenhall Influence of the Friendly Society 3. Friendly societies can be traced back to Roman law during the reign of Emperor Nero in AD 55. Concerning the history of friendly societies, see Hardy 1888 Journal of the Institute of Actuaries 246-250. In 1796 England had 7200 friendly societies with more than 600000 members. However, the first friendly society legislation in England was promulgated only in 1793.

2 Cook, Deakin and Hughes Mutuality and Corporate Governance 11; Volkskas Beleggingskorporasie Bpk v Oranje Benefit Society 19781 SA 45 (A) 48, where the phrase "committee of officers" is used.

3 Dugard et al International Law 19. Britain annexed Natal in 1843. It must be remembered that the Netherlands did not colonise the Orange Free State or the South African Republic (ZAR). These two states were established as independent states as a result of a treaty signed between the Boers and the United Kingdom.

$4 \quad$ Dugard et al International Law 19. The Pretoria Convention of 1881 and the London Convention of 1884 confirmed the independence of these two states. Interestingly, the South African Republic and the Orange Free State could trade only with each other. They were not allowed to enter into treaties with any other state, for example the Netherlands, for trading purposes.

5 Dugard et al International Law 20-21. Before the Union of South Africa was established in 1910, the different provinces were subjected to the Westminster system. 
which did not regulate, for example, any Cape Colony or Natal friendly societies or companies, unless that society or company was registered under the 1909 Act. $^{6}$ As another example, section 21(5) of the 1909 Act repealed the Transvaal Societies and Associations Incorporations Ordinance Act, 1903 (hereafter the Ordinance Act). ${ }^{7}$ However, a society incorporated under the Ordinance Act could continue as a Transvaal society, provided that any such society was registered as a company. ${ }^{8}$ On the other hand, section 51 of the Friendly Societies Act 25 of 1956 of the Union of South Africa refers to the Cape Colony's Friendly Society Act 5 of 1892 and Natal's Friendly Society Act 20 of $1862 .{ }^{9}$ It would appear that these Acts were repealed by section 52 of the 1956 Act. ${ }^{10}$ This implies that friendly societies in Natal and the Cape Colony continued separately from the Transvaal friendly societies up until $1956 .^{11}$

The following paragraphs try to explain the problem statement of this article.

A friendly society is a legal person with the object of not making profits and to some degree promotes the principle of mutuality between members of the society. ${ }^{12}$ Although this principle could be challenged in South African

$6 \quad$ Section 202(2) of the Transvaal Companies Act 31 of 1909 states: "The provisions of this Act shall not be construed as applying to a building society, a friendly society, or a trade union, unless the society or union is, at the commencement of this Act, registered under the Limited Liability Companies Laws". For the relevance of a friendly society to a trade union, see SACTWU v Feltex Sick Benefit Fund 20039 BPLR 5141 (PFA).

7 Section 21(5) of the Transvaal Companies Act 31 of 1909 states: "Notwithstanding the repeal by this Act of the Societies and Associations Incorporation Ordinance 1903, the provisions of the said Ordinance shall continue to apply to every society or association which has been registered thereunder: Provided that any such society or association may, on complying with the provisions of this Chapter, become registered as a company."

8 A circumstance similar to close corporations in the present. A close corporation incorporated under the Close Corporations Act 69 of 1984 can continue to exist as a close corporation although the 1984 Act has been repealed.

$9 \quad$ Section 51 of the Friendly Society Act 25 of 1956 states: "So much of the Friendly Societies Act, 1892 ... and the Friendly Societies Amendment Act, 1895 (Act 26 of 1895), of the Cape of Good Hope, and Law no. 20 of 1862 and Law no. 7 of 1897 of Natal, are hereby repealed." The Natal friendly societies also continued to exist until the 1956 Act. The Transvaal Societies and Associations Incorporation Ordinance, 1903 (the Ordinance Act) is not mentioned in the 1956 Act. Strictly speaking, such societies could still exist and be subjected to the regulations of the Ordinance Act.

10 Section 52 of the Friendly Societies Act 25 of 1956 states: "This Act shall apply also in the Territory". The territory means the Union of South Africa, which included the four provinces, Transvaal, Orange Free State, Natal and Cape of Good Hope.

11 The Transvaal Companies Act 31 of 1909 repealed only the Ordinance Act, and not the actual registered societies.

12 The Friendly Societies Act 25 of 1956 s 5(1) requires the registration of a friendly society. See in general Wettenhall Influence of the Friendly Society 4, where a friendly society is described as a business concept that embraces mutuality. 
friendly society law on the basis of the share capital or the issuing of shares that takes place in order to commence the business activities of a society, the 1956 Act nevertheless uses the terms "shareholder" and "member", although it is not clear how the term shareholder should be interpreted in friendly society law in this regard. For example, do shareholders include all members or only certain members? The issuing of shares is generally contrary to the principle of mutuality in friendly society law. Shares indicate the principle of demutualisation. Profits are to be shared by the shareholders as investors and not by members as the "owners" of the society. ${ }^{13}$

In this article the relative status of a member and a shareholder of a friendly society under the 1956 Act is discussed and is briefly compared to that in Australian friendly societies and the Australian interpretation of members and shareholders and the payment of dividends. This is important for understanding the legal differences between friendly society members and friendly society shareholders from both a South African and an Australian perspective and how both jurisdictions view dividends. Before we focus on this comparison, the Companies Act 61 of 1973 defines a member as including a shareholder, even if the company has share capital. ${ }^{14}$ Section 1 of the Companies Act 71 of 2008 clearly defines the differences between members and shareholders. A member refers to non-profit companies (or companies without share capital) only and a shareholder refers to profit companies (or companies with share capital) only. ${ }^{15} \mathrm{~A}$ friendly society is, technically speaking, not an enterprise for profit, since the profits are mutually owned by the society's members and profits are used to settle members' claims. Nevertheless, friendly societies in South Africa may make use of share capital to commence business operations or to raise additional capital for future business endeavours and to anticipate a dividend. ${ }^{16}$

13 The Friendly Societies Act 25 of 1956 s 1 defines a member and officer; Roth Informal Micro-Finance Schemes 22; Cook, Deakin and Hughes Mutuality and Corporate Governance 13 . Members who have bought shares in a friendly society are actually equal in ranking in the society; one vote per member instead of the number of shares held by each member as shareholder. The emphasis is not on shareholding as such. Hardy 1888 Journal of the Institute of Actuaries 250 friendly societies were seen as a form of partnership.

Companies Act 71 of $2008 \mathrm{~s} 1$ states that a member for example of a "non-profit company, means a person who holds membership in, and specified rights in respect of, that non-profit company, as contemplated in Schedule 1", and a shareholder as "subject to s 57(1), means the holder of a share issued by a company and who is entered as such in the certificated or uncertificated securities register, as the case may be".

16 Friendly Societies Act 25 of 1956 with reference to s 13(s) it is not very clear what classes of shares can exist in friendly society law; Roth Informal Micro-Finance Schemes 17. 
In addition, there is a clear difference in the 2008 Act between a member and a shareholder and this article attempts to illustrate the differences between friendly society members and shareholders in South Africa and Australia. To emphasise the differences, the article discusses the concept of a loss ratio in South Africa and the importance of loss ratios to indicate "profits" in friendly society law, and how it differs from Australian perspectives to indicate "profits". In section 13(n), the Friendly Societies Act 25 of 1956 requires friendly societies' constitutions (rules of the society or memoranda of incorporation) to regulate the manner in which losses and/or profits should be calculated without explaining the formula for calculating such loss ratios. ${ }^{17}$ In Australia and after 1999 it is not a requirement that company constitutions should regulate or explain/calculate "profits". The purpose of loss ratio calculations will be briefly discussed from a South African perspective and compared with the Australian perspectives on loss ratios. The article attempts to explain profits by making use of different loss ratio calculations in South Africa and to determine if loss ratio calculations are also important from an Australian perspective, and discusses whether dividend payments should be in cash only.

\section{Business operations of a friendly society}

The Prudential Authority does not embrace technology to the same extent as the Companies and Intellectual Property Commission (CIPC), for example to allow for public searches pertaining to who the company directors are, company registration numbers, company business addresses, relevant communication between CIPC and the company etcetera. ${ }^{18}$ This lack of technology is problematic for third persons who want to enquire into the registration status of a friendly society, who the officers are etcetera. Besides the lack of technological innovation in this regard, section 2 of the 1956 Act briefly defines the business operations of friendly societies as follows: the relief of or maintenance for members during minority, old age, widowhood, sickness or other infirmity, whether bodily or mental; ${ }^{19}$ the granting of annuities to members; ${ }^{20}$ the granting of benefits to

Friendly Societies Act 25 of 1956 s 13(n) states "the manner of determining profits and losses and of disposing of such profits or providing for such losses". Disposing could imply dividends to be paid to the shareholders, as an example.

18 CIPC $2020 \mathrm{https}: / /$ eservices.cipc.co.za/Search.aspx. On the Financial Services Conduct Authority (FSCA) website only registered financial services providers can be searched and no searches exist for friendly societies. friendly society in Chambers v Fedsure Group Staff Income Security Scheme 1999 11 BPLR 254 (PFA). Friendly Societies Act 25 of 1956 s 2(1)(b). 
members for surgical operations, dental care or medicines as benefits; ${ }^{21}$ the payment of a sum of money on the birth of a member's child; ${ }^{22}$ the payment of a sum of money on the death of a member; ${ }^{23}$ the payment of a lump sum against fire or other contingencies of the implements of the trade of a members or its calling; 24 the payment of a lump sum when a member leaves the employment of his employer; ${ }^{25}$ the relief of the effects of unemployment; the advancement of the education or training of members or their children; and/or ${ }^{26}$ any other form of business as directed by the Government Gazette. ${ }^{27}$ Most of the above benefits are currently regulated by other legislation. For example, healthcare (surgical operations, dental care, medicines) is regulated by the Medical Schemes Act 131 of 1998 . To provide these benefits, the enterprise must be registered as a medical aid company and, as such, friendly societies can no longer provide these benefits. The same applies to fund managers specialising in annuities, which are regulated by the Pension Funds Act 24 of $1956 .{ }^{28}$ In addition, a friendly society member obtains the above relief/benefits for paying a monthly premium to the friendly society. Although a friendly society is prohibited from conducting the business activities of an insurer in South Africa, the above benefits are exceptions and to some degree they are also part of the business activities of registered life insurers, for example funeral (death benefits) cover. ${ }^{29}$

Section 2(2) of the Friendly Societies Act states that regarding the monthly premium payments to acquire one or more of the benefits listed above, the

$21 \quad$ Friendly Societies Act 25 of 1956 s 2(1)(c).

22 Friendly Societies Act 25 of 1956 s 2(1)(d)(i).

23 Friendly Societies Act 25 of 1956 s 2(1)(d)(ii). Pertaining to pension fund payments as friendly society benefits, see Williams v Mustek Group Income Plan 20048 BPLR 6000 (PFA); Reddy v Massmart Group Retirement Fund 20048 BPLR 5963 (PFA); Lasker v Cape Municipal Pension Fund Disability Income Benefit Scheme 20047 BPLR 5866 (PFA).

$24 \quad$ Friendly Societies Act 25 of 1956 s 2(1)(e).

$25 \quad$ Friendly Societies Act 251956 s 2(1)(f).

$26 \quad$ Friendly Societies Act 251956 s 2(1)(h).

27 Friendly Societies Act 25 of $1956 \mathrm{~s}$ 2(1)(i). In this regard see Moonsamy $v$ Uniserv Income Security Scheme 20047 BPLR 5907 (PFA); Cook, Deakin and Hughes Mutuality and Corporate Governance 11 states the following: "... it is necessary to understand that societies are special statutory creatures, in a statutory straightjacket, and that unlike individuals, partnerships or companies in this respect, they have no choice in the matter of the business which they carry on".

The Pension Funds Act 24 of 1956 as amended by the Pension Funds Amendment Act 11 of 2007 by $\mathrm{s} 1$ (c) to define an administrator relevant to $\mathrm{s} 13 \mathrm{~B}(1)$. A fund manager could be an administrator.

Gen N 457 in GG 30987 of 25 April 2008 (Determination of an Increased Maximum Amount of Benefit to be Provided by a "Friendly Society", as Envisaged in Section 7(2)(B) of the Long-Term Insurance Act, 1998). The maximum benefit payable by a friendly society is $\mathrm{R} 7500$. 
premium payer is the actual member. ${ }^{30}$ In the event the member becomes mentally ill and is unable to contribute any monthly premiums, the mentally ill person remains a member of the society and the member's beneficiary is still entitled to receive any benefit. For example, the member may receive a lump sum payment on the birth of a member's child. ${ }^{31}$ On the other hand, the 1956 Act also makes reference to share capital, implying the existence of shareholders, making this form of business enterprise very unique. In the next paragraph we will consider the term "shareholder". Before we focus on this term, however, it is necessary to note that the CIPC does not employ relevant technology to search for shareholders on its website; nor does the Prudential Authority for friendly societies. It is suggested that the Prudential Authority should consider appropriate technology (website searches) to allow the public an opportunity to distinguish between the members and the shareholders of a friendly society, and to understand the consequences of allowing for public searches in this regard. The consequences will be discussed in the following paragraph.

\section{Members and shareholders of friendly societies}

Section 2(2) of the 1956 Act briefly explains the circumstances under which a friendly society cannot be considered as such. This section states that in the event a non-beneficiary contributes monthly premiums on behalf of a member, the enterprise is most likely not a friendly society. It is problematic if a member is unable to pay monthly premiums or contributions due to ill health and someone pays them on his or her behalf and is not a beneficiary of any benefit. In addition to the difficulty caused by this distinction between beneficiaries and non-beneficiaries, it should also be mentioned that a member or non-member is (could be) a shareholder of a friendly society if the constitution or memorandum of incorporation makes provision for share capital and if the constitution, for example, clearly states the circumstances when a member or non-member could acquire shares. ${ }^{32}$ It would appear that the Friendly Societies Act, 1956, emphasises that the constitution should distinguish between shareholders and members, but if the constitution is silent, section 1 of the Friendly Societies Act gives no guidance on how to understand the differences/technicalities between

30 The Friendly Societies Act 25 of 1956 ss 2(2)(a) and 15 refers to valid claims submitted to the society on the death of a member.

31 In this case a curator is appointed by the High Court to look after the personal affairs of the mentally ill person.

32 Cook, Deakin and Hughes Mutuality and Corporate Governance 12 states as follows: "... societies are frequently referred to as being mutual although this term is difficult to define and is not used in building society legislation. Societies raise most of their funds through share investments and membership is incidental to investing". 
members and shareholders. For example, a shareholder who is both a nonmember and a non-beneficiary who makes payment on behalf of a member is subject to section 2(2), as illustrated earlier. However, the similarities between shareholders and members are to some degree better explained in section 1 of the Mutual Banks Act 124 of 1993, which clearly states that all members of a mutual bank are also shareholders of that bank. A mutual bank's purpose is to contribute to the principle of mutuality - the members are the owners of the bank. In the Friendly Societies Act one may also focus on section 14(1)(a) to understand whether a member of a friendly society is in fact a shareholder of that society in the event that the constitution is not too clear. Section 14(1)(a) states the following: "If he purports to affect any right of a creditor of the society, other than a member or shareholder thereof ...."

Section 14(1)(a) regulates the amendment of the rules of a society. An amendment is valid only if it does not affect the rights of creditors other than members or shareholders. If a member includes a shareholder, the legislature could have defined members as shareholders, but the mere fact that the legislation uses "or" in section 14(1)(a) indicates that members and shareholders are not one and the same thing. For this reason we have a unique legal relationship in South Africa where members are not automatically shareholders $; 3$ unless the member acquires shares ${ }^{34}$ On the other hand, section 15 explains the separateness of members and shareholders if so regulated in the society's constitution. The constitution is a contract among the society members/shareholders themselves and between the society and its members or shareholders. ${ }^{35}$ To employ relevant technology (friendly society, shareholder and member searches) most of the difficulties discussed above can be prevented in practice. Since the constitution or memorandum of incorporation of a friendly society is public information, the Prudential Authority should make use of relevant technology to make it possible for third persons to access the constitutions of friendly societies.

33 See Rube $v$ KPMG South Africa 20048 BPLR 5966 (PFA) for the relevance of benefits in the rules of a friendly society; Mavundla $v$ Flex-o-Thene Provident Fund 20045 BPLR 5739 (PFA) discusses when a society is liable to pay benefits; Thorne $v$ Meihuizen Provident Fund 200011 BPLR 1288 (PFA); Oliver v Packard Group Pension Fund 20048 BPLR 5945 (PFA); Oosthuyzen v Road Accident Fund 2019 $\mathrm{JOL} 40807$ (FB), where it is explained that an insurance premium includes a refund of a premium.

Roth Informal Micro-Finance Schemes 17; Ansell Treatise on Friendly Societies 150. No reference is made in this book to share capital in the constitution of a friendly society. 


\section{Members and shareholders regulated in the constitution of a friendly society}

The Registrar (Prudential Authority) of Friendly Societies will register the society's rules or constitution only if the rules are financially sound. ${ }^{36}$ What constitutes financially sound rules? No definition is given in section 1 to explain what is meant. Rules may be financially sound in the event the members pay their monthly contributions to their society as regulated in section 2 of the 1956 Act. However, financial soundness may also include a technical component such as the minimum share capital required to commence with business, or the Registrar may prescribe a specific loss ratio percentage. ${ }^{37}$ In addition, it is unclear whether financial soundness should also include actuarial valuation of the business activities of a society or loss ratios etcetera. ${ }^{38}$ In addition, the Friendly Societies Act does not regulate different share classes, and the Registrar may exercise its discretion to allow only ordinary shares instead of cumulative preference shares. A cumulative preference shareholder has a right to receive unpaid dividends of previous financial years, making the rules financially "unsound". ${ }^{39}$ It is uncertain how the Registrar (Prudential Authority) will prescribe rights and duties generally to different classes of shareholders as a method of making the rules financially sound. 40

\section{Constitution and shareholders of a friendly society}

Section 4 of the Companies Act, 2008 states the requirements for declaring distributions/dividends to company shareholders. For example, the company must be liquid and solvent and must be able to pay its creditors within 12 months after the date of distribution of payment. ${ }^{41}$ Since the constitution is a contract between companies and shareholders, one may argue that dividend payments could be a personal right. ${ }^{42}$ The Friendly Societies Act has no similar section 4 provisions to effect distribution/dividend payments to shareholders. In addition, the constitution may stipulate that the payment of dividends is based on the discretionary

\footnotetext{
$36 \quad$ Pension Funds Act 24 of 1956 s 5(4)(a)(i).

$37 \quad$ See as an example Table 1.

38 Pension Funds Act 24 of 1956 s 5(2).

39 Delport New Companies Act Manual 31-33.

40 A preferential shareholder is entitled to an annual dividend or cumulative dividends, and could be referred to as a permanent shareholder due to the unlikelihood of selling preferential shares to another person.

41 Section 4(1)(a-b) of the Companies Act 71 of 2008; Delport New Companies Act Manual 53.

$42 \quad$ Du Plessis and Alveras 2014(b) C\&SLJ 552-559.
} 
power of the committee of officers. In the absence from the constitution of a discretionary power or there being no relevant dividend provisions for this, the payments or future payments of dividends could be ultra vires acts. ${ }^{43} \mathrm{An}$ ultra vires act is void in the common law. In Tek Corporation Provident Fund, the Supreme Court of Appeal held the following concerning ultra vires acts committed by trustees of pension funds: ${ }^{44}$

\begin{abstract}
What the trustees may do with the fund's assets is set forth in the rules. If what they propose to do (or have been ordered to do) is not within the powers conferred upon them by the rules, they may not do it. They have no inherent and unlimited power as trustees to deal with a surplus as they see fit, notwithstanding their fiduciary duty to act in the best interests of the members and beneficiaries of the fund. It may seem odd to speak of powers being beyond the reach of the trustees and the employer when the rules empower them to amend the rules but the contradiction is more apparent than real. First, their substantive powers at any given moment are circumscribed by the rules as they are at that moment. The fact that power to change the rules exists is irrelevant when assessing whether or not the particular exercise of power in question was intra or ultra vires.
\end{abstract}

Although a friendly society is managed by officers - not trustees - the constitution generally makes provision for the way in which dividends should be paid. ${ }^{45}$ However, some South African friendly societies are welfare organisations, and in this regard the 1956 Act does not prohibit these societies from issuing shares and or paying dividends. ${ }^{46}$ Even if the society is labelled as a welfare association/society, members will submit their claims for payment and the relationship between payment and the settlement of claims indicates the "profitability" of the welfare society. The constitution or rules may be very specific as to how the loss ratio (profitability) should be calculated in South Africa at the end of the financial year for welfare societies. ${ }^{47}$ A practical example is given in Table $1: 48$

43 Du Plessis and Alveras 2014(b) C\&SLJ 552-559.

44 Tek Corporation Provident Fund v Lorentz 19994 SA 884 (SCA) 898G-899A.

45 Tek Corporation Provident Fund v Lorentz 19994 SA 884 (SCA) 898G-899A. The same rationale is relevant to friendly societies. A friendly society's constitution or rules has a similar legal consequence as a pension fund constitution or rules - the rules must regulate proposed acts as intra vires acts.

$46 \quad$ Van der Merwe Die Stokvel 4-7. A stokvel or stockfair may be similar to a friendly society as they both help members when they are in financial need. A stockfair works on a rotational principle for the payment of benefits, unlike a friendly society.

47 Hardy 1888 Journal of the Institute of Actuaries 261 uses a table to show a profit or a surplus. In this table, benefits paid (claims) and other expenses are $£ 37321$ and the surplus is $£ 885382$, so the loss ratio $37321 / 885382$ is $4 \%$. In other words, the surplus or profit amounts to $96 \%$. This was the average loss ratio for 6567 societies on 31 December 1880 . The membership, including that of burial societies, exceeded 4 million members in total.

48 This footnote includes a resource that a researcher may consult for further reading; Manchester Unity Friendly Society 2017 https://www.manchesterunity.org.nz/wp- 


\section{Table 1}

\begin{tabular}{|l|l|}
\hline Annual premium collected by the society & $\mathrm{R} 900000$ \\
\hline Less unearned premium reserve & $\mathrm{R} 50000$ \\
\hline Less claims incurred but not settled ${ }^{49}$ & $\mathrm{R} 150000$ \\
\hline Less claims & $\mathrm{R} 650000$ \\
\hline Total profits or (loss) for the financial year & $\mathrm{R} 50000$ \\
\hline $\begin{array}{l}\text { Loss ratio (expenses/annual premium or } 850000 / 900 \\
000)\end{array}$ & $95 \%$ \\
\hline
\end{tabular}

In Table 1 the friendly society's loss ratio is $95 \% .^{50}$ In other words, most of the annual premium collected from members (R900 000) has been paid in benefits to members as an expense (R850 000). ${ }^{51}$ Administrative costs such as office rent, staff remuneration and telephone expenses can easily exceed $4 \%$ of the annual premium collected or, in other words, the loss ratio can easily be $99 \%(95 \%+4 \%)$ inclusive of administrative costs. ${ }^{52}$ The above formula ignores administrative costs. In these circumstances a dividend

content/uploads/2015/02/Manchester-Unity-Annual-Report-31-May-2017.pdf 13. Here a breakdown is provided for annual premiums collected and annual claims paid. For example, regarding funeral cover, the society collected NZ\$320 336 and paid NZ\$1 064076 in claims. In this regard, the loss ratio for funeral cover is approximately three times more than the annual premium - a great loss. The annual premium for medical services is NZ\$846 842 and the claims are NZ\$657 499, giving a loss ratio of $77 \%$ and total profits of only NZ $\$ 189343$. This excludes the unearned premium reserve.

49 This footnote includes a resource that a researcher may consult for further reading; Ancient Order of Foresters in Victoria Friendly Society Ltd $v$ Lifeplan Australia Friendly Society Ltd [2018] HCA 43 para 5 as to whether profits should include anticipated profits or actual profits only. The court held the following view: "Unrealised profits are actual profits. Profits are made when they are earned, recognised when they are brought into the accounts, and realised when they accrue, that is to say when a legal right arises to receive payment. As a matter of ordinary accounting practice, profits are seldom recognised before they accrue, but this is a matter of prudence only; in a proper case they may be recognised before they accrue". Hardy 1888 Journal of the Institute of Actuaries 262 gives an indication of the total number of claims submitted to societies in New Zealand from 1873 to 1882. Hardy 1888 Journal of the Institute of Actuaries 252. During the 1800s friendly societies were obliged to report their claims/losses to the parliament of the United Kingdom. Parliament collected data to understand the society industry better. If a society did not report any claims, the society could be deregistered as a friendly society. Today we have similar circumstances in that insurers must draft their financial statements and submit them to the FSCA. This includes an actuarial valuation report as regulated by the Short-Term Insurance Act 53 of 1998. costs could generally be $6 \%$ or so. The author does not define administrative expenditure. This could mean that in order to settle claims $6 \%$ administrative expenditure was required. 
should not be paid. In the event that the constitution does not regulate administrative costs as an expense, this simply means that dividends of $5 \%$ or less $(100 \%-95 \%)$ could be paid to shareholders. The loss ratio formula does not give a clear picture of the financial position of the society because a $5 \%$ dividend payment plus administrative costs equals an actual loss ratio of $104 \%(95 \%+4 \%+5 \%)$. In this regard, it is very important to list all the expenses of a society in order to calculate the most reliable loss ratio. Compare this to Table 2:

\section{Table 2}

\begin{tabular}{|l|l|}
\hline Annual premium collected by the society & R900 000 \\
\hline Less unearned premium reserve & R50 000 \\
\hline Less claims incurred but not settled & $R 0$ \\
\hline Less claims & R100 000 \\
\hline Total profits or (loss) for the financial year & $R 750000$ \\
\hline Loss ratio (expenses/annual premium or 150 000/900 & $17 \%$ \\
$000)$ & \\
\hline
\end{tabular}

When comparing $17 \%$ to $95 \%$, even if the telephone, staff salaries and/or other expenses are added it is highly unlikely that $17 \%$ would reach $95 \% .{ }^{53}$ For the sake of argument, with all other administration costs (expenses equal $4 \%)$ the loss ratio would be $21 \%(17 \%+4 \%) .{ }^{54}$ In this regard, one may argue that only the committee of officers can decide whether dividend payments should be made, since nearly $80 \%$ of the annual premiums received are actual profits and are technically available for distribution. ${ }^{55}$ The constitution may provide for cash dividend payments to each shareholder (or shareholder as member) or, instead of cash, an increase in member benefits (if the constitution disallows cash payments). ${ }^{56}$ Therefore, the distribution of dividends or distributions in friendly society law are unique

53 Hardy 1888 Journal of the Institute of Actuaries 258 describes how big the funds were in 1886. For example, the Ancient Order of Foresters had 582000 members and $£ 3,4$ million in the fund.

$54 \quad$ See in general Lifeplan Australia Friendly Society Ltd $v$ Wolf [2016] FCA 248 para 461 for an example of the overheads of the business.

55 See in general the Friendly Societies Act 25 of 1956 . The Registrar may prescribe actuarial assistance, but this is not a requirement in the Act.

56 The maximum payable friendly society benefits to a South African member in the event of a disability is equal to R7 500 only. PPS 2009 http://www.powerbrokers.co.za/uploads/File/pdf/product_suppliers/pps/PPS_SURP LUS_REBATE_ACCOUNT.pdf. PPS insurance allocates profits (not cash payments) to a member's account, which is known as a rebate account. When the member or contributor reaches the age of 65 , the rebate is paid to the member in a lump sum. 
from a South African perspective. Members are entitled to be paid claims and to receive dividends.

\section{Possible specific regulations in friendly society constitutions pertaining to profits - a personal right example from Australia}

Although the above-mentioned loss ratio calculation is an indication of profits, friendly societies must draft annual financial statements. ${ }^{57}$ The financial statements, specifically the income statement, must comply with "generally accepted accounting principles" and must contain additional income or expenses that are not relevant to loss ratios. ${ }^{58} \mathrm{~A}$ practical example is non-operating revenue/income; income generated from renting fixed property etcetera. ${ }^{59}$ Although rent contributes to income, it is not income that should be used to calculate the loss ratio. The loss ratio uses only premiums received and claims paid, and the relationship between them is expressed as a percentage. In this regard, the cash flow statement is useful for knowing the liquidity of the society when calculating loss ratios. By focussing on the cash flow statement, a better understanding of the loss ratio calculation is obtained. ${ }^{60}$ Besides the latter technical explanation of liquidity, the rules or constitution could also require approval from a general meeting of members in favour of paying dividends - similar to the Companies Act 61 of $1973 .{ }^{61}$ Obviously, depending on the wording of the constitution, the society can either require an annual general meeting of members or a meeting of shareholders to decide on dividend payments. ${ }^{62}$ The constitution may require that the financial statements of the society be presented to the annual general meeting to allow the members an opportunity to investigate the loss ratio in order to make an informed decision to pay dividends or not. ${ }^{63}$ However, this is not clearly regulated in

57 Delport New Companies Act Manual 114.

58 Chen 2020 https://www.investopedia.com/terms/i/incomestatement.asp. This article has been updated by David Kindness and explains the different concepts relevant to the income statement.

59 Delport New Companies Act Manual 114-118.

60 See Ancient Order of Foresters in Victoria Friendly Society Ltd $v$ Lifeplan Australia Friendly Society Ltd [2018] HCA 43 para 5 for the differences between actual and anticipated profits.

$61 \quad$ Pretorius et al Hahlo's South African Company Law 566.

62 Nelson 1877 Journal of Statistical Society of London 44-45. A general meeting of members was referred to as an "annual movable committee". A dispute between a member and a society was subjected to arbitration. Nelson 1877 Journal of Statistical Society of London 48. In 1876 the number of deaths for the Manchester Unity of Odd Fellows was 47419 and total membership was 508 013. The payment of a death benefit was generally made at a flat rate, and 
friendly society law, and it is also possible to require the committee of officers to recommend a dividend first. Once a dividend is recommended and depending on the wording of the constitution, the recommendation must be approved/declared by the annual general meeting. In this regard, the members will have the final say on whether to pay a dividend or not. In regard to this explanation of the recommendation and declaration of dividends, it is not possible to regulate dividends as an explicit personal right in the constitution or memorandum of incorporation. ${ }^{64}$ In this case, recommendation and declaration are requirements/conditions for the payment of a dividend. If the constitution does not make reference to the requirement of a recommendation and or declaration, the payment of a dividend could be a personal right. In Sumiseki Materials Co Ltd v Wambo Coal Pty Ltd, the Federal Court of Australia focussed on a personal right to a dividend in the constitution of the company and how to balance this right with the board's discretion not to pay a dividend. ${ }^{65}$ Needless to say, the Federal Court rejected the well-known company law principle that dividends are a management decision and instead ruled that the constitution should take precedence. ${ }^{66}$

Further, the registration of a friendly society occurs in two separate steps provisional registration and final registration. ${ }^{67}$ It is possible to add additional rules relevant to final registration, such as rules relating to dividend payments. If the Registrar approves the final registration of the society (five years after the date of registration), the Registrar may recommend a loss ratio formula as a method for calculating dividend payments and calculating what the expenses should be. ${ }^{68}$ The Registrar may also recommend that a loss ratio must always be compared to the cash flow statement of the society or subject to actuarial valuation. ${ }^{69}$ For practical purposes, we can do a very simple comparison of the cash flow statement and the loss ratio calculation

one could use the premium income and claims expense to calculate the loss ratio or the profitability of the friendly society. Voluntary member resignation influences the number of premium or monthly contributions to be collected. Thus, fewer members implies less premium income and thus a higher loss ratio. Pretorius et al Hahlo's South African Company Law 566-571.

65 Sumiseki Materials Co Ltd v Wambo Coal Pty Ltd [2014] NSWCA 326. See in general Du Plessis and Alveras 2014(a) C\&SLJ 312-332. See in general Du Plessis and Alveras 2014(a) C\&SLJ 312-332. Friendly Society v Commissioner for Inland Revenue 58 SATC 243; Apollo Tobacco CC v Commissioner for South African Revenue 74 SATC 204. 
to indicate the relevance of liquidity for dividend payments. For our purposes, we will focus on the following loss ratio:

\section{Table 3}

\begin{tabular}{|l|l|}
\hline Total cash at the beginning of 2020 & $\mathrm{R} 100000$ \\
\hline Annual premium collected by the society in 2020 & $\mathrm{R} 900000$ \\
\hline Less unearned premium reserve & $\mathrm{R} 50000$ \\
\hline Less claims incurred but not settled & $\mathrm{R} 0$ \\
\hline Less claims & $\mathrm{R} 100000$ \\
\hline Total profits/cash or (loss) for the financial year & $\mathrm{R} 750000$ \\
\hline $\begin{array}{l}\text { Loss ratio (expenses/annual premium or } 150 \text { 000/900 } \\
000)\end{array}$ & $17 \%$ \\
\hline
\end{tabular}

By comparing the above with the cash flow statement in Table 4, the following positive liquidity is observed: ${ }^{70}$

\section{Table 4}

\begin{tabular}{|l|l|}
\hline Beginning of 2020 & $\mathrm{R} 100000$ \\
\hline End of 2020 & $\mathrm{R} 750000$ \\
\hline Increase in cash & $750 \%$ or 7.5 \\
\hline
\end{tabular}

In addition to the simple comparison above, the constitution may contain similar provisions that compare the cash flow statement with the loss ratio in order to understand whether the society is indeed solvent and/or liquid before paying any dividends. ${ }^{71}$ In the example in Table 4 above, the society increased its cash as a result of the extremely low loss ratio shown in Table 3 , indicating the profitability of the society. ${ }^{72}$ Although the constitution is a contract and there are no statutory provisions that the constitution must

$70 \quad$ This footnote includes a resource that a researcher may consult for further reading; Annual Financial Report 2017 https://www.manchesterunity.org.nz/wpcontent/uploads/2015/02/Manchester-Unity-Annual-Report-31-May-2017.pdf 32. Notes on the cash flow statement. In the previous financial year the cash balance was NZ\$1 474508 and in 2017 it was NZ\$2 261 867, which indicates that the overall losses suffered by the society were less than the annual premiums received. See Ancient Order of Foresters in Victoria Friendly Society Ltd $v$ Lifeplan Australia Friendly Society Ltd [2018] HCA 43 paras 5-6 for a general discussion of the importance of the in and out flow of capital.

72 See in general Lifeplan Australia Friendly Society Ltd v Wolf [2016] FCA 248 para 456 on how to project future profits relevant to business run-offs. A run-off implies that no new policies are to be accepted after a certain date and the emphasis is on the profitability of the existing policies. It should be remembered that new policies may reduce the loss ratio of the friendly society since those policies contribute to an increase in annual premiums. 
contain clauses to regulate dividend payments, we suggest that the committee of officers should at least acknowledge the relevance of a cash flow statement before paying any dividends. ${ }^{73}$

\section{Provisional and final registration of friendly societies and its relevance to profits}

In South Africa a friendly society is required to be registered provisionally for five years, after which the society should apply for final registration. ${ }^{74}$ In this regard the Registrar may provide dividend guidelines, stating that a dividend or distribution payments should follow only after final registration. ${ }^{75}$ This will ensure, to some degree, the financial soundness of the society for the first five years. ${ }^{76}$ In the event that the rules make no provision for distribution or are very vague, it is possible to change the rules or constitution to be more specific on the way future distributions or dividends should be recommended/declared, authorised or paid. ${ }^{77}$ It must be borne in mind that, once the process is initiated to amend the rules pertaining to dividends, no distribution is allowed. This is the result of G Lamparelli and $S$ Hefele $v$ Eskom Pension Fund. ${ }^{78}$ In this adjudication the pension fund adjudicator held that an amended rule is not enforceable unless it is duly registered by the Registrar of Pensions (known as the Prudential Authority in the present).

The rules can also state that a declaration/recommendation, authorisation or payment should occur only at the end of the society's financial year. ${ }^{79}$ It is also possible to pay dividends more frequently during a financial year, since the Friendly Societies Act, 1956 does not regulate interim or final dividends. ${ }^{80}$ The constitution could also provide for a fixed dividend rule or

Friendly Societies Act 25 of 1956 s 5(9) unless the Registrar requires the assistance of an actuary.

Friendly Societies Act 25 of 1956 in s 5(3).

Friendly Societies Act 25 of 1956 in s 5(5).

See in general Du Plessis and Alveras 2014(a) C\&SLJ 312-332.

Friendly Societies Act 25 of 1956 in s 5(9). The Registrar can require that distribution/dividend payments should be subjected to actuarial scrutiny, instead of approving an appropriate loss ratio calculation relevant to the financial soundness of the rules.

G Lamparelli and $S$ Hefele $v$ Eskom Pension Fund (unreported) case numbers PFA/GA/2881/01/NJ and PFA/3000/01/NJ of 27 September 2001 7; Friendly Societies Act 25 of 1965 in s 14(4) states that the Registrar will approve an amended rule only if the amendment does not affect the financial soundness of the society.

Delport New Companies Act Manual 58.

Friendly Societies Act 25 of 1956 in s 5(9). The Registrar may require that interim dividends should be subjected to actuarial scrutiny to establish the financial soundness of dividends. 
distribution rule. For example, every shareholder is entitled to a 20c dividend for every share held by the shareholder. This could be similar to the legal position in Sumiseki Materials Co Ltd v Wambo Coal Pty Ltd, where the Federal Court of Australia discussed the importance of a personal right to a dividend regulated in a constitution. This could be equally relevant in a South African context. ${ }^{81}$

\section{Friendly societies in Australia}

\subsection{Brief general background}

The Friendly Societies (South Australia) Act, 1919, was repealed and replaced by the Friendly Societies (South Australia) Act, 1997.82 The Friendly Societies (Tasmania) Act, 1997 repealed the Friendly Societies (Tasmania) Act of 1888.83 The Tasmanian Act has reference to the Friendly Societies (Victoria) Act, 1996. ${ }^{84}$ The Friendly Societies (Victoria) Act (and Code), 1996 also has application in South Australia; the Friendly Societies (South Australia) Act, 1997 refers to the Queensland's Friendly Societies Act (and Code), 1997 for regulation purposes relating to such matters as the payment of share capital and dividends to friendly society shareholders etcetera. ${ }^{85}$ These Acts were repealed by the Financial Sector Reform Act, 1999, except for certain sections of Queensland's Friendly Society Code in South Australia and Queensland. ${ }^{86}$ These sections are relevant to anything

81 Du Plessis and Alveras 2014(b) C\&SLJ 552-559.

82 For other relevant friendly society legislation in Australia, see Abrook $v$ Paterson (No 2) 59 FCR 364 (1995) para 2, for example the Friendly Societies (Queensland) Act, 1913; see in general Wettenhall Influence of the Friendly Society 32 for an introduction to relevant legislation; $R v$ Holmes, Ex Parte Manchester Unity Independent Order of Oddfellows in Victoria 147 CLR 65 (1980) para 3, which states that a friendly society could be conducting the business of an insurer, although not registered as such. The members of a society also cannot be subjected to industrial action (to a strike).

83 Nelson 1877 Journal of Statistical Society of London 43, where friendly societies consisted of different courts or lodges managed from a central court. A constitution could also state that each court should be self-governed. A court could establish a company and purchase shares in a company. In this regard see Wettenhall Influence of the Friendly Society 114.

84 Friendly Societies (Tasmania) Act, 1997 in s 3.

85 Friendly Societies (Queensland) Act, $1997 \mathrm{~s} 5$ refers to Victoria's Code and Act; Sampford 1997 https://www.parliament.qld.gov.au/documents/explore/ResearchPublications/Legisl ationBulletins/lb0897ks.pdf 8; Green 1984 Labour History 72-73. More than one third of members belonged to friendly societies in Victoria, paying a flat fee or similar monthly contributions to visit doctors. More than $40 \%$ of the doctors in Victoria participated in this business model as if they were employed by the society. The doctors were miserably underpaid by the societies.

86 Financial Sector (South Australia) Act, 1999, where s 29(1) states the following: "The following provisions continue to apply on and after the transfer date in relation to 
done or omitted to be done only before the date of conversion (which is referred to as the transfer date) of a society to a company as a result of the financial reform in 1999. In addition, the Friendly Societies (Queensland) Act (and Code), 1997 had approximately 39 sections, ${ }^{87}$ while the Friendly Societies Code of Queensland had approximately 490 sections that regulated friendly societies in Queensland and South Australia. ${ }^{88}$ The effect of the financial reform was to convert friendly societies into companies and to regulate that they continue as companies and legal enterprises in future. ${ }^{89}$ For example, currently in Australia a friendly society is a registered company whereas in South Africa a friendly society remains an unregistered company. ${ }^{90}$ Before we focus on the implications of the Life Insurance Act, 1995, which since 1999 regulates friendly societies as a type of life insurer,

anything done or omitted to be done before that date..."; Sampford 1997 https://www.parliament.qld.gov.au/documents/explore/ResearchPublications/Legisl ationBulletins/lb0897ks.pdf 2.

This footnote includes resources that a researcher may consult for further reading; In Re Grand United Order of Free Gardeners Friendly Society Ltd [2008] FCA 1537 para 3, the Court referred to the Queensland Code to ascertain the allocation of unclaimed benefits. See in general Wettenhall Influence of the Friendly Society 235 for an explanation of medicine as a society's business object; Wilkinson 2006 Money Management 5. Building societies continued to exist after the implementation of the Financial Reform Act in 2006. In this regard the Friendly Society (Victoria) Code, 1996 it seems, is still relevant to building societies; Walsh 2017 https://treasury.gov.au/sites/default/files/2019-03/Friendly-Societies-of-

Australia.pdf. The President of the Friendly Societies of Australia wrote a letter to the Australian Treasury on 23 May 2017 stating that friendly societies incorporated in terms of the Corporations Act, 2001 and which issued shares in terms of the Corporations Act, 2001 would be demutualised. In other words, a society would no longer be mutually owned by its members; Cook, Deakin and Hughes Mutuality and Corporate Governance 16. Although traditionally a member is a shareholder, the emphasis is not on shareholding. In the event of demutualisation, a shareholder is not necessarily a member. Instead, s/he is an investor who controls the company (which is in fact a society) through the value of his/her shares. For a friendly society as a club, see in general Mount Isa City Council v Mount Isa Irish Association Friendly Society Ltd [2018] QCA 222 para 1. The club owned assets and the assets were let out for income. Financial Sector Reform (Queensland) Act 27 of 1999 s 17. Also see s 56, which explains which parts of the Queensland Friendly Society Code are still relevant. Financial Sector Reform (Queensland) Act 27 of 1999 ss 5(1) and 53(b). The date of conversion is referred to as the transfer date; Cook, Deakin and Hughes Mutuality and Corporate Governance 43. Once a friendly society is transformed into a different enterprise, it is difficult to keep the advantages associated with such societies. It is also impossible to reverse such a process to keep existing friendly societies as true societies.

90 Financial Sector Reform (Queensland) Act 27 of 1999 in s 56(3)(I); Re Grand United Order of Free Gardeners Friendly Society Ltd [2008] FCA 1537 para 1. This friendly society has continued as a company limited by guarantee since 1999 or after the promulgation of the Financial Sector Reform Act, 1999. It was incorporated as a friendly society in 1958. If a friendly society had no shares at the "transfer date" or date of conversation to a company, the society automatically became a company limited by guarantee. 
we will give a brief background on the shareholder/society relationships and the payment of dividends prior to the financial reform of $1999 .{ }^{91}$

\subsection{Brief background on the Friendly Societies Queensland Code before the 1999 financial reform}

Section 56 of the Queensland Code regulates the main business objects/activities of a friendly society. These are, briefly, to provide welfare benefits and physiotherapy, for the relief and maintenance of members in the event of birth, sickness, disability, retirement, old age, unemployment, education etcetera. ${ }^{92} \mathrm{~A}$ body proposed to be a friendly society could be successfully registered if there are 25 members requesting its registration. ${ }^{93}$ The members should all be adults, and a member includes a shareholder or they could be separate persons. ${ }^{94}$ The constitution or rules of the society regulates member benefits and share capital. ${ }^{95}$ What is interesting is that, before the actual registration of the society, the 25 members may proceed to elect the first board of directors of the society. In this regard, the same company law terminology is used to describe the managers of a society board of directors. ${ }^{96}$ Section 71 of the Code regulates the legal nature of the society's rules or constitution. For example, the rules constitute a contract among the members/shareholders themselves and between the society and the members/shareholders. Section 82 of the Code makes provision for a unique member, namely "joint members"; in other words, one member pays monthly contributions in exchange for benefits, and the benefits could be shared jointly with another person once the society is liable to pay benefits. ${ }^{97}$

91 Sampford 1997 https://www.parliament.qld.gov.au/documents/explore/Research Publications/LegislationBulletins/lb0897ks.pdf 20. There are more than 200 friendly societies in Australia. The largest ten societies account for more than $80 \%$ of the assets of the industry. A number of societies offer either financial or non-financial services. Those that offer financial services, for example, are regulated by the Life Insurance Act, 1995. See for example a non-financial friendly society in Carroll $v$ Shillinglaw [1906] 3 CLR 1099 paras 1-2.

Friendly Societies (Queensland) Act, 1997 in s 56(a-e) of the Code. See in general Wettenhall Influence of the Friendly Society 2, which states that a friendly society is actually a social welfare concept. Also see Hardy 1888 Journal of the Institute of Actuaries 245 . The purpose of a friendly society was mainly to assist with death and sickness benefits. Later it evolved into helping members socially or as a form of companionship and into engaging in charity. See in general the main business objects of a friendly society in The Friendly Societies Medical Association Inc $v$ Commissioner of Taxation 4 SASR 96 (1972) para 1. Friendly Societies (Queensland) Act, 1997 in s 59(1) of the Code. See in general Weinbren and James 2005 Labour History 87-103.

94 Friendly Societies (Queensland) Act, 1997 in s 59(5) of the Code.

95 Friendly Societies (Queensland) Act, 1997 in s 59(4) of the Code.

96 Friendly Societies (Queensland) Act, 1997 in s 62 of the Code.

97 Rex 2016 https://www.bsa.org.uk/information/consumer-factsheets/savings/what-isthe-difference-between-a-shareholder-and-a. In the United Kingdom building 
In Australia the society's register of members should indicate whether a member is a joint member or not. Whether a "joint shareholder" could have existed in friendly society law in Australia falls outside the scope of this article. Nevertheless, it is an interesting concept. For example, one person subscribes to shares and the subscriber and another person are entitled to receive dividends from the society. ${ }^{98}$ In addition, a member may withdraw his or her contributions paid to the society if so provided for in the rules of the society. ${ }^{99}$ In this regard, the person will still continue to act as a member of the society. ${ }^{100}$

Currently, life friendly societies are defined and regulated in section $16 \mathrm{~F}$ of the Life Insurance Act, 1995, which regulates societies selling life insurance benefits. ${ }^{101}$ However, societies that sell health insurance are not subject to the provisions of the Life Insurance Act and fall outside the scope of this article. ${ }^{102}$ In this regard, share capital and dividend/distribution of profits is regulated in the Life Insurance Act. Before we focus on the share capital and dividend provisions of this Act, we will briefly explain shares in the Friendly Societies Code of Queensland, to note any differences from the Life Insurance Act as it stands today.

\subsection{Classes of shares before the financial reform}

The share capital of a society can be divided into different classes of shares. In terms of the Code, a society may issue permanent shares and/or redeemable preference shares. ${ }^{103}$ Although it appears that there are only two classes of society shares in Australia - permanent and redeemable shares - the rules or constitution of a society may make provision for different rights relevant to these, such as permanent shares as preference or ordinary shares. ${ }^{104}$ A permanent share is a fully paid-up share and in

friendly societies also refers to joint holders of a share account; Cook, Deakin and Hughes Mutuality and Corporate Governance 1.

Friendly Societies (Queensland) Act, 1997 in s 83(3) of the Code.

Friendly Societies (Queensland) Act, 1997 in s 101(2)(b) of the Code.

See in general Weinbren 2013-2014 Magazine of the Historical Association 12-16.

Section $16 \mathrm{~F}(3)(\mathrm{d})$ of the Life Insurance Act, 1995 explains the different kinds of policies for friendly societies. In chief, they are life insurance or any other kind of insurance policy as explained in note 2 of $\mathrm{s} 16 \mathrm{~F} 3(\mathrm{~d})$.

Life Insurance Act, 1995 in s 16ZB, the date of conversion or date of transfer of the society's main business was, for example, health insurance. In terms of the Financial Sector Reform Act, 1999 the society may continue with health insurance. Health insurance is currently regulated by the Private Health Insurance Act, 2007. The Life Insurance Act, 1995 in s $16 \mathrm{~N}$ states briefly that the society's rules are valid on the day of acceptance of the rules.

Friendly Societies (Queensland) Act, 1997 in ss 219 and 220 of the Code.

Boros and Duns Corporate Law 298-299. 
addition it could have rights associated with preference shares (to receive a dividend first). ${ }^{105}$ However, even if different classes were to exist, all the classes rank equally in the event of the winding up of the society. In other words, all classes will share equally in the distribution of the assets or profits of the society. ${ }^{106}$ In addition, the constitution or rules will specify whether a preference share is cumulative or non-cumulative. ${ }^{107}$ The difference between a cumulative and non-cumulative share is simply the following. In the event that a society refuses to pay a dividend in a particular year and decides to pay a dividend in the following financial year, the shareholder has no right to claim the arrear dividends unless the shares are cumulative. ${ }^{108}$ In South Africa a society's rules or constitution could have similar provisions relevant to cumulative and non-cumulative shares. What is important is that in the Queensland Code a share belonging to a specific class must have the same par value. See the example in Table 5.

Table 5

\begin{tabular}{|l|l|}
\hline Class of share & Nominal or par value of the share \\
\hline $\begin{array}{l}2000 \quad \text { redeemable preference } \\
\text { shares }\end{array}$ & \$3 Australian dollar per share \\
\hline 1000 permanent shares & $\$ 1$ Australian dollar per share \\
\hline
\end{tabular}

Although the phrase "financially sound rules" is not referred to in the Act or Code, the rules will be registered only if they are appropriate. In other words, we assume that the rules are appropriate when the nominal value of the shares is sufficient to conduct the business of the society. ${ }^{109}$ What is also very interesting is the selling or transfer of shares. ${ }^{110} \mathrm{~A}$ transfer is allowed only if the society has consented to it, as regulated in section 223 of the Code. In other words, members who are not shareholders must give their consent to the selling of shares by a shareholder. ${ }^{111}$ The constitution or memorandum of incorporation of South African friendly societies could have

\footnotetext{
105 Friendly Societies (Queensland) Act, 1997 in s 229(e) of the Code.

106 Friendly Societies (Queensland) Act, 1997 in ss 227(1-2) and 228 of the Code which refers to preference shares as a class of permanent shares. See in general Du Plessis and Alveras 2014(a) C\&SLJ 312-332.

107 Friendly Societies (Queensland) Act, 1997 in s 229 (a-d) of the Code.

108 Boros and Duns Corporate Law 298-304.

109 Friendly Societies (Queensland) Act, 1997 in s 220(3 of the Code).

110 Mount Isa City Council v The Mount Isa Irish Association Friendly Society Ltd [2018] QCA 222 para 1. The relevance of administrative law is discussed from the point of view of a friendly society.

111 Compare briefly to Du Plessis and Alveras 2014(a) C\&SLJ 312-332 with reference to the Corporations Act, 2001 relevant to registered companies share capital.
} 
similar provisions relevant to selling shares. If no such provisions exist in the constitution, this means that a shareholder of a South African friendly society can transfer and sell shares without obtaining any permission. In the Queensland Code the society may not give any financial assistance to obtain shares in the society, as against the position in South Africa, unless the rules or constitution of the South African society prohibits financial assistance. ${ }^{112}$

\subsection{Shareholder dividends before the financial reform}

To authorise a dividend, the board of directors must exercise their discretion to pay dividends. The dividend payment may be subjected to ranking preference shareholders will receive a dividend first. The dividend payment can be either in cash or in the additional issue of shares to the shareholders. ${ }^{113}$ Shares issued instead of cash are referred to as bonus shares. The rules of a society must authorise the payment of any dividends. If the rules do not authorise payment, then irrespective of the discretionary power of the board to authorise dividends, the shareholder is not allowed to receive any dividend payment. ${ }^{114}$ Dividends are paid out of the profits of the society and/or the share premium account maintained specifically for this purpose. ${ }^{115}$ The constitution may contain a formula for calculating profits, similar to the loss ratio in Table 1 discussed earlier. Although it is an offence in Queensland to pay dividends out of share capital, in South Africa it is probably not an offence - such payments can be regulated by the constitution. ${ }^{116}$ After converting a friendly society to a company (with the main object of offering life cover) as a result of the financial reform of 1999 , the society is automatically subject to the Life Insurance Act, 1995. ${ }^{117}$

\section{Dividends/distributions and share capital in the Life Insurance Act, 1995 after the 1999 financial reform}

\footnotetext{
112 Friendly Societies (Queensland) Act, 1997 in s 224(1) of the Code.

113 Friendly Societies (Queensland) Act, 1997 in s 231 of the Code.

114 Friendly Societies (Queensland) Act, 1997 in s 231 (2-3) of the Code.

115 Friendly Societies (Queensland) Act, 1997 in s 240(2) of the Code explains the relevance of the share premium account and what it can be used for, such as the payment of dividends.

116 Friendly Societies (Queensland) Act, 1997 in s 231(4) of the Code.

117 Re Grand United Order of Free Gardeners Friendly Society Ltd [2008] FCA 1537 para 2 . This friendly society specialised in funeral policies. Therefore, it is taken that such a society is registered under the Life Insurance Act, 1995 as a result of Item 11 of Schedule 8 of the Financial Sector Reform Act, 1999. Item 11 states that a registered friendly society, after the transfer date or date of conversation, is taken to be registered under the Life Insurance Act, 1995
} 
In the preceding paragraphs it is clear that a shareholder and/or member can be either the same person or two independent persons. ${ }^{118}$ However, in section 242 of the Life Insurance Act, provision is made to continue as society members only. ${ }^{119}$ In addition, section $242(2)$ states that a member who is also a shareholder - could be listed on the postal voters' roll to vote for suitable director candidates, for example. ${ }^{120}$ In addition to this technical explanation of members of life societies, section 61 explains the relevance of distributions/dividends and shareholder capital. Shareholders contribute to share capital and they are entitled to receive "distributions" (dividends). ${ }^{121}$ Section 61(2) states the following:

In the application to a company other than a company limited only by shares, a provision of this Division that includes the expression 'shareholder' is to be read as follows:

(a) The provision is to be read as if 'members' were substituted for 'shareholders' and

(b) In the case of subsection 62(1), the resulting reference to 'members' funds' is to be read as reference to an account of the company representing funds that are not a statutory fund.

The terms member and shareholder are used interchangeably in the Life Insurance Act - section 61(2)(a) above. ${ }^{122}$ Earlier we discussed loss ratio calculations for friendly societies in South Africa to indicate the profitability of the society. The loss ratio calculation may have a similar application in Australia; that is, to understand the profitability and members' expectations of receiving a dividend/distribution. In Australia a loss ratio calculation plays a less important role in the Life Insurance Act, since any distributions are subject to additional statutory provisions in the Act. For example, operating

118 See in general Lifeplan Australia Friendly Society Ltd $v$ Wolf [2016] FCA 248 para 81. Lifeplan purchased the share capital in Norwich Union Funeral Plan Management Pty (Ltd). This transaction merged the funeral policies of the two businesses; Lifeplan 2020 https://www.aubiz.net/company/lifeplan-australiafriendly-society-limited-087649492. Lifeplan friendly society is limited by shares and is an Australian public company.

119 Re Grand United Order of Free Gardeners Friendly Society Ltd [2008] FCA 1537 paras 2-3.

120 Life Insurance Act, 1995 in s 242(b)(i-ii) of the Code.

121 See in general Lifeplan Australia Friendly Society Ltd $v$ Wolf [2016] FCA 248 para 472. The Federal Court did not ask Mr Dermody to address the Court on the subject of dividends.

122 Lifeplan Australia Friendly Society Ltd $v$ Wolf [2016] FCA 248 para 402. In this case the Federal Court of Australia, in a 134-page judgment, had to decide whether employees of a friendly society have a fiduciary duty to the society. In this regard, Wolf took confidential business information of the society to promote his own future endeavours. 
profit in the Life Insurance Act is defined as the difference between income and expenses. Income may include the proceeds of rental agreements. ${ }^{123}$ The allocation of operating profits should be added to the shareholders' retained profits account only, which is commonly referred to as the members' account. ${ }^{124}$ The distribution of the retained profits to shareholders/members can be effected only by following the provisions in section 62 of the Life Insurance Act; namely, to transfer the retained or operating profits to the shareholders'/members' funds, or to transfer them to another statutory fund, or to distribute them to the owners of the policies as increased benefits in that fund (no actual cash payment of a dividend). ${ }^{125}$ The directors can distribute the retained profits only on the advice of an actuary pertaining to future liquidity. ${ }^{126}$ In other words, there is no right to receive a fixed cash payment distribution as in the case of South African societies. ${ }^{127}$ Directors in Australia have no sole discretionary power to distribute any profits as member benefits without consulting an actuary. ${ }^{128}$ In South Africa a friendly society is not subject to actuarial scrutiny relevant to distributions/dividends unless the constitution regulates it specifically or on the advice of the Registrar/Prudential Authority. ${ }^{129}$ There is no provision in South Africa for a written actuarial report, and no provision that requires how retained profits should be distributed. ${ }^{130}$ In other words, the loss ratio calculation in Australia is subject to actuarial scrutiny and is therefore more technical than the unregulated loss ratio calculation in South Africa. In addition, it is possible to distinguish between different classes of shares in a life company, each with its own distribution rights subject to the written opinion of an actuary. ${ }^{131} \mathrm{~A}$ life friendly society cannot unilaterally decide to

123 Life Insurance Act, 1995 in s 58(1); see in general Cook, Deakin and Hughes Mutuality and Corporate Governance 15. Members as shareholders in friendly societies do not really have a claim to dividends; they have a claim to share in the surplus in the event of the liquidation of the society. Life Insurance Act, 1995 in ss 59(2)(d) and 60(1) explains what the statutory expenses are etc.

125 Life Insurance Act, 1995 in s 62(d).

126 See in general Lifeplan Australia Friendly Society Ltd $v$ Wolf [2016] FCA 248 para 452 for the relevance of actuarial evidence during a trial. In this case, the experts for the applicant and defendant agreed to compile a joint expert report stating the matters they agreed on and those they disagreed on relevant to the liquidity of a friendly society.

127 See para 7 in the main text.

128 See in general Boros and Duns Corporate Law 328-330.

129 See para 4 in the main text.

130 Life Insurance Act, 1995 in s 63(3)(a-b). The Friendly Society Act 25 of 1956 in s 14(3) may be interpreted to be relevant to loss ratio calculations, or generally the constitution of a South African society should contain the method/formula for calculating a loss ratio as required by s 13(s); Hardy 1888 Journal of the Institute of Actuaries 254 states the importance of actuarial valuation of the society's profit/fund. Life Insurance Act, 1995 in s 230 AF (b)(ii). 
issue additional shares or rights to acquire additional shares in the friendly society as a company; the company must first obtain the permission of the Australian Prudential Regulation Authority (APRA), for example, to issue additional shares and at what nominal value. ${ }^{132}$ Besides the above, the Australian Securities Investments Commission (ASIC) is responsible not only for regulating corporate markets but also for employing relevant technology (a company search tool and Equifax reports) to search for company directorships, company registration dates, share divisions, court actions taken against the company/director(s), insolvency applications etcetera. ${ }^{133}$ This allows any third person to make an informed decision whether to invest in a particular company or to conclude any contracts with a company because of the composition of its board of directors. The company search tool is an easy way of increasing corporate integrity in the markets. In this regard, South Africa must start embracing technology, especially "online search tools" relevant to friendly societies.

\section{Conclusion}

The Australian Life Insurance Act, 1995, states that every member is a shareholder of a society. A similar provision exists in South Africa, depending on the interpretation of section 14(1)(a) of the Friendly Societies Act, 1956, and the relevant constitutional provisions of the society. ${ }^{134}$ It is clear that the wording of a constitution or memorandum of incorporation plays an important role in South Africa, for example, shareholders' right to a dividend could have a similar legal consequence to the Sumiseki Materials Co Ltd case. ${ }^{135}$ This case serves is persuasive on why the society's constitution or memorandum of incorporation in South Africa creates personal rights to receive dividends. It is evident that the society's constitution or memorandum of incorporation regulates the processes for receiving a dividend. For example, the committee of officers recommends a dividend subject to the general meeting's declaration thereof and is a more technical process for receiving a dividend. ${ }^{136}$ The society's constitution or memorandum of incorporation may require a declaration from either the members or shareholders in an annual general meeting. This depends on the wording of the memorandum of incorporation. ${ }^{137} \mathrm{~A}$ South African friendly

\footnotetext{
132 Life Insurance Act, 1995 in s 230AE(1)(a).

133 ASIC 2020 https://www.equifax.com.au/businesscreditexpress/resource/asiccompany-and-director-search.

134 See para 3 in the main text above.

135 See para 6 in the main text above.

136 See para 7 in the main text above.

137 See para 6 in the main text above.
} 
society uses a loss ratio formula for calculating profitability and the society's constitution or memorandum of incorporation may regulate this formula indicative of dividend payments. ${ }^{138}$ In the Life Insurance Act, 1995 actuarial scrutiny is required to establish the profitability of a society as a company and not a loss ratio formula. ${ }^{139}$ Irrespective of whether the board decides to pay a dividend or not, the final decision rests with the actuary that uses its own calculations. In terms of the Life Insurance Act, dividends are not paid in cash. ${ }^{140}$

\section{Bibliography}

\section{Literature}

Ansell Treatise on Friendly Societies

Ansell C A Treatise on Friendly Societies (Baldwin and Cradock London 1835)

Boros and Duns Corporate Law

Boros E and Duns J Corporate Law (Oxford University Press Melbourne 2007)

Cook, Deakin and Hughes Mutuality and Corporate Governance

Cook J, Deakin S and Hughes A Mutuality and Corporate Governance: The Evolution of UK Building Societies Following Deregulation (Working Paper No 205) (ESCR Centre for Business Research, University of Cambridge Cambridge 2001)

\section{Delport New Companies Act Manual}

Delport P The New Companies Act Manual: Including Close Corporations and Partnerships (LexisNexis Durban 2011)

Dugard et al International Law

Dugard J et al Dugard's International Law: A South African Perspective $5^{\text {th }}$ ed (Juta Cape Town 2018)

Du Plessis and Alveras 2014(a) C\&SLJ

Du Plessis JJ and Alveras S "The Payment of Dividends: Legal Confusion, Complexities and the Need for Comprehensive Reform" 2014 C\&SLJ 312332

See para 5 in main text above.

See para 9 in main text above.

See para 9 in main text above. 
Du Plessis and Alveras 2014(b) C\&SLJ

Du Plessis $\mathrm{JJ}$ and Alveras A "A Shareholder's Contractual Right to a Dividend and a Company's Oppressive Conduct in Withholding Dividend Payments: Sumiseki Materials Co Ltd v Wambo Coal Pty Ltd" 2014 C\&SLJ 552-559

Green 1984 Labour History

Green DG "The 1918 Strike of the Medical Profession against the Friendly Societies of Victoria" 1984 Labour History 72-87

Hardy 1888 Journal of the Institute of Actuaries Hardy GF "Friendly Societies" 1888 Journal of the Institute of Actuaries 245348

Nelson 1877 Journal of Statistical Society of London

Nelson FGP "Some Statistics of the Affiliated Order of Friendly Societies (Odd Fellows and Foresters)" 1877 Journal of Statistical Society of London 42-89

Pretorius et al Hahlo's South African Company Law

Pretorius JT et al Hahlo's South African Company Law through the Cases: A Source Book $5^{\text {th }}$ ed (Juta Cape Town 1997)

Roth Informal Micro-Finance Schemes

Roth J Informal Micro-Finance Schemes: The Case of Funeral Insurance in South Africa (Working Paper No 22) (International Labour Office Geneva 2000)

Van der Merwe Die Stokvel

Van der Merwe DHC Die Stokvel: 'n Ondernemingsregtelike Studie (University of the Free State Bloemfontein 1996)

Weinbren 2013-2014 Magazine of the Historical Association

Weinbren D "The World in 1913: Friendly Societies in History" 2013-2014 Magazine of the Historical Association 12-16

Weinbren and James 2005 Labour History

Weinbren D and James B "Getting a Grip: The Roles of Friendly Societies in Australia and Britain Reappraised" 2005 Labour History 87-103

Wettenhall Influence of the Friendly Society

Wettenhall RS The Influence of the Friendly Society Movement in Victoria 1835-1920 (PhD-thesis University of Melbourne 2019) 
Wilkinson 2006 Money Management

Wilkinson J "Friendly Societies FUM Grows to \$7Billion" 2006 Money Management 5

Case law

Australia

Abrook v Paterson (No 2) 59 FCR 364 (1995)

Ancient Order of Foresters in Victoria Friendly Society Ltd $v$ Lifeplan Australia Friendly Society Ltd [2018] HCA 43

Carroll v Shillinglaw [1906] 3 CLR 1099

Lifeplan Australia Friendly Society Ltd v Wolf [2016] FCA 248

Mount Isa City Council $v$ The Mount Isa Irish Association Friendly Society Ltd [2018] QCA 222

Re Grand United Order of Free Gardeners Friendly Society Ltd [2008] FCA 1537

$R v$ Holmes, Ex Parte Manchester Unity Independent Order of Oddfellows in Victoria 147 CLR 65 (1980)

Sumiseki Materials Co Ltd v Wambo Coal Pty Ltd [2014] NSWCA 326

The Friendly Societies Medical Association Inc v Commissioner of Taxation 4 SASR 96 (1972)

\section{South Africa}

Apollo Tobacco CC v Commissioner for South African Revenue 74 SATC 204

Chambers v Fedsure Group Staff Income Security Scheme 199911 BPLR 254 (PFA)

Family Benefit Friendly Society v Commissioner for Inland Revenue 58 SATC 243

G Lamparelli and $S$ Hefele $v$ Eskom Pension Fund (unreported) case numbers PFA/GA/2881/01/NJ and PFA/3000/01/NJ of 27 September 2001 
Lasker v Cape Municipal Pension Fund Disability Income Benefit Scheme 20047 BPLR 5866 (PFA)

Mavundla v Flex-o-Thene Provident Fund 20045 BPLR 5739 (PFA)

Moonsamy v Uniserv Income Security Scheme 20047 BPLR 5907 (PFA)

Oliver v Packard Group Pension Fund 20048 BPLR 5945 (PFA)

Oosthuyzen v Road Accident Fund 2019 JOL 40807 (FB)

Reddy v Massmart Group Retirement Fund 20048 BPLR 5963 (PFA)

Rube v KPMG South Africa 20048 BPLR 5966 (PFA)

SACTWU v Feltex Sick Benefit Fund 20039 BPLR 5141 (PFA)

Tek Corporation Provident Fund v Lorentz 19994 SA 884 (SCA)

Thorne v Meihuizen Provident Fund 200011 BPLR 1288 (PFA)

Volkskas Beleggingskorporasie Bpk v Oranje Benefit Society 19781 SA 45 (A)

Williams v Mustek Group Income Plan 20048 BPLR 6000 (PFA)

\section{Legislation}

\section{Australia}

Corporations Act, 2001

Financial Sector Reform (Queensland) Act 27 of 1999

Financial Sector (South Australia) Act, 1999

Friendly Societies (South Australia) Act, 1919

Friendly Societies (South Australia) Act, 1997

Friendly Societies (Tasmania) Act, 1888

Friendly Societies (Tasmania) Act, 1997

Friendly Societies (Queensland) Act, 1913 
Friendly Societies (Queensland) Act (and Code), 1997

Friendly Societies (Victoria) Act (and Code), 1996

Life Insurance Act, 1995

Private Health Insurance Act, 2007

\section{South Africa}

Cape Colony Friendly Society Act 5 of 1892

Close Corporations Act 69 of 1984

Companies Act 61 of 1973

Companies Act 71 of 2008

Friendly Societies Act 25 of 1956

Medical Schemes Act 131 of 1998

Mutual Banks Act 124 of 1993

Natal Friendly Society Act 20 of 1862

Pension Funds Act 24 of 1956

Pension Funds Amendment Act 11 of 2007

Short-Term Insurance Act 53 of 1998

Transvaal Companies Act 31 of 1909

Transvaal Societies and Associations Incorporation Ordinance, 1903

\section{Government publications}

Gen N 457 in GG 30987 of 25 April 2008 (Determination of an Increased Maximum Amount of Benefit to be Provided by a "Friendly Society", as Envisaged in Section 7(2)(B) of the Long-Term Insurance Act, 1998)

\section{Internet sources}

ASIC 2020 https://www.equifax.com.au/businesscreditexpress/resource/ asic-company-and-director-search 
Australian Securities and Investments Commission 2020 ASIC Company and Director Search https://www.equifax.com.au/businesscreditexpress/ resource/asic-company-and-director-search accessed 26 January 2020

Chen 2020 https://www.investopedia.com/terms/i/incomestatement.asp Chen J 2020 Income Statement https://www.investopedia.com/terms/i/ incomestatement.asp accessed 9 September 2020

CIPC 2020 https://eservices.cipc.co.za/Search.aspx

Companies and Intellectual Property Commission 2020 Companies and Intellectual Property Commission eServices https://eservices.cipc.co.za/ Search.aspx accessed 25 January 2020

Lifeplan 2020 https://www.aubiz.net/company/lifeplan-australia-friendlysociety-limited-087649492

Lifeplan 2020 Lifeplan: An Australian Public Company https://www.aubiz.net/company/lifeplan-australia-friendly-society-limited087649492 accessed 1 September 2020

Manchester Unity Friendly Society 2017 https://www.manchesterunity.org .nz/wp-content/uploads/2015/02/

Manchester-Unity-Annual-Report-31-May-2017.pdf

Manchester Unity Friendly Society 2017 Annual Financial Report of Manchester Unity Friendly Society for the Year Ended 31 May 2017 https://www.manchesterunity.org.nz/wpcontent/uploads/2015/02/Manchester-Unity-Annual-Report-31-May2017.pdf accessed 15 January 2020

PPS 2009 http://www.powerbrokers.co.za/uploads/File/pdf/product suppliers/pps/PPS_SURPLUS_REBATE_ACCOUNT.pdf

Professional Provident Society 2009 Surplus Rebate Account 2009 http://www.powerbrokers.co.za/uploads/File/pdf/product_suppliers/pps/PP S_SURPLUS_REBATE_ACCOUNT.pdf accessed 10 July 2020

Rex 2016 https://www.bsa.org.uk/information/consumer-factsheets/ savings/what-is-the-difference-between-a-shareholder-and-a

Rex S 2016 What is the Difference between a Building Society Shareholder and a Depositor? https://www.bsa.org.uk/information/consumerfactsheets/savings/what-is-the-difference-between-a-shareholder-and-a accessed 12 September 2020

Sampford 1997 https://www.parliament.qld.gov.au/documents/explore/ researchpublications/legislationbulletins/lb0897ks.pdf 
Sampford K 1997 National Uniform Regulation of Friendly Societies and the Friendly Societies (Queensland) Bill 1997 (Legislation Bulletin No 8/97) https://www.parliament.qld.gov.au/documents/explore/ResearchPublicatio ns/LegislationBulletins/lb0897ks.pdf accessed 13 June 2020

Walsh 2017 https://treasury.gov.au/sites/default/files/2019-03/FriendlySocieties-of-Australia.pdf

Walsh M 2017 A Letter from the President of the Friendly Societies of Australia to the Australian Treasury on 23 May 2017 https://treasury.gov.au/sites/default/files/2019-03/Friendly-Societies-ofAustralia.pdf accessed 4 August 2020

\section{List of Abbreviations}

APRA

ASIC

C\&SLJ

CIPC

FSCA

PPS

ZAR
Australian Prudential Regulation Authority Australian Securities and Investments Commission Company and Securities Law Journal Companies and Intellectual Property Commission Financial Services Conduct Authority Professional Provident Society South African Republic (Zuid-Afrikaansche Republiek) 